\title{
Systematic review article \\ Human platelet-rich plasma as a biological stimulant for proliferation and differentiation of mesenchymal stem cells
}

\author{
Dewi Sukmawati ${ }^{1,2}$, Helsy Junaidi ${ }^{3}$, Rahimi Syaidah ${ }^{1,2}$ \\ ${ }^{1}$ Department of Histology, ${ }^{3}$ Postgraduate Student, ${ }^{2}$ Doctoral Program in Biomedical Science, Faculty of Medicine, Universitas \\ Indonesia, Jln. Salemba Raya No.4 Jakarta 10430, Indonesia
}

(Received: March $2021 \quad$ Revised: April $2021 \quad$ Accepted: April 2021)

Corresponding author: Dewi Sukmawati. Email: ds_histoui@outlook.com; dewi.sukmawati@ui.ac.id

\begin{abstract}
Platelet is one of the cells within the blood that have potential in regenerative therapy. Recently platelet-related products got special attention due to the abundance of growth factors and easy availability and processing. With the robust in cell-based therapy, platelet-rich plasma (PRP) has been intensively studied for its potential to substitute the fetal bovine serum (FBS) as the supplement in cell culture. Our study aimed to investigate the use of human PRP in mesenchymal stem cells (MSC) culture and its related effect on stem cell biology. We searched in vitro studies that used human PRP as a supplementing factor on human MSCs culture. From the initial 172 studies, 14 studies fulfilled the selection criteria and were analysed. The results showed that the sources of MSCs were varied, including adipose tissue, bone marrow, and dental tissue. The PRP concentration showing the best effects was ranged from 10 to $20 \%$. In addition, most of the studies demonstrated the superiority of PRP to FBS in promoting the proliferation and differentiation of MSCs in vitro. Therefore, PRP could be an alternative to FBS in supporting a xeno-free culture system. Studies are needed to reveal the mechanism of PRP in maintaining the physiology of MSCs.
\end{abstract}

Keywords: Platelet-rich plasma; mesenchymal stem cells; cell culture; proliferation; differentiation; xeno-free.

\section{INTRODUCTION}

$\mathrm{T}$ o date, successes in regenerative medicine have included regenerating non-functional tissue or organ damage caused by trauma, congenital (acquired) abnormalities, and some end-stage diseases $(1,2)$. Mesenchymal stem cells (MSCs) are among the promising stem cells for cell-based therapy. MSCs are known to have the pluripotent ability to differentiate into several cell types, including adipocytes, osteoblasts, and chondrocytes (3). To define the population of MSCs, there are minimal criteria according to The International Society for Cellular Therapy (ISCT). First, the cells have the ability to adhere on the plastic culture dish when cultured in vitro. Second, the cells positively express $(>95 \%)$ the surface antigen of CD73, CD90 and CD105; but negatively $(\leq 2 \%)$ for the surface antigen of CD45, CD34, CD14 or CD11b, CD79 $\alpha$ or CD19, and HLADR. Third, the cells are able to differentiate into mesodermal cell types (i.e., chondrocytes, osteoblasts, and adipocytes) when cultured under specific conditions (4).

The origin of MSCs was revealed to be derived from many tissues and organs, including bone marrow, brain, lymphoid organs, kidney, muscle, etc (5). Due to its plasticity and multipotency, MSCs have been applied in various diseases and showed the advantages to promote tissue regeneration in neurological disorders, cardiac ischemia, diabetes, and musculoskeletal tissue (6-9).

Until recently, most of the procedures in stem cell expansion and propagation were still using animal sera, such as fetal bovine serum (FBS). FBS is widely used for a broad spectrum of cell types, including cell lines (10). Therefore, with FBS content, it may hamper additional applications of the cells in clinical settings. Good manufacturing practices have required that the expansion of stem cells for therapeutic purposes in patients should avoid any xeno materials and must be safe from zoonotic disease transmission $(11,12)$.

In the last decade, platelet-rich plasma (PRP) has attracted the attention of researchers as it has the potential to replace the use of animal sera in stem cell expansion. PRP is a concentrate of platelet that is rich in plasma protein, and obtained from the centrifugedwhole blood (13-16). PRP contains fibrinogen and abundant growth factors released by the platelets. These growth factors play important roles in promoting tissue regeneration and repair. PRP must be activated to release various growth factors and regulatory proteins, such as platelet-derived growth factor (PDGF), epidermal growth factor (EGF), transforming growth factor-beta (TGF-ß), insulin-like growth factors (IGFs), and vascular endothelial growth factor (VEGF) $(14,17,18)$. These growth factors are known to play crucial roles in stem cell physiology, such as proliferation, migration, and differentiation. This study aims to review and identify the use of PRP as a potential biological growth factor for MSC culture that provides an alternative to animal sera, as well as its potential mechanism in maintaining MSC physiology in vitro.

\section{MATERIALS AND METHODS}

The literature search strategy was carried out through PubMed/MEDLINE by following the PRISMA-P protocol for systematic reviews and meta-analyses. 
The following keywords were used for the search: "platelet-rich plasma" AND "mesenchymal stem cell culture", "platelet-rich plasma" AND "cell-based therapy and platelet-rich plasma" AND "xeno-free". In addition, relevant existing articles were added from our library. The selection process can be seen in Figure 1 . The collected articles were then sorted based on the inclusion and exclusion criteria.

The inclusion criteria consisted of the following: literature needed to be available in English, published within the last 10 years (2010-2020), and freely accessible through PubMed; furthermore, the research had to have been conducted using in vitro experimental methods and with a focus on the use of platelet-rich plasma as a growth factor supplement in human mesenchymal stem cell culture. Literature published before 2010, non-English articles, articles not available in full-text form, review articles, research that did not document an in vitro study, experiments that did not use human mesenchymal stem cells, and those that did not use PRP or other forms of platelet lysate as a growth factor during cell culture were excluded.

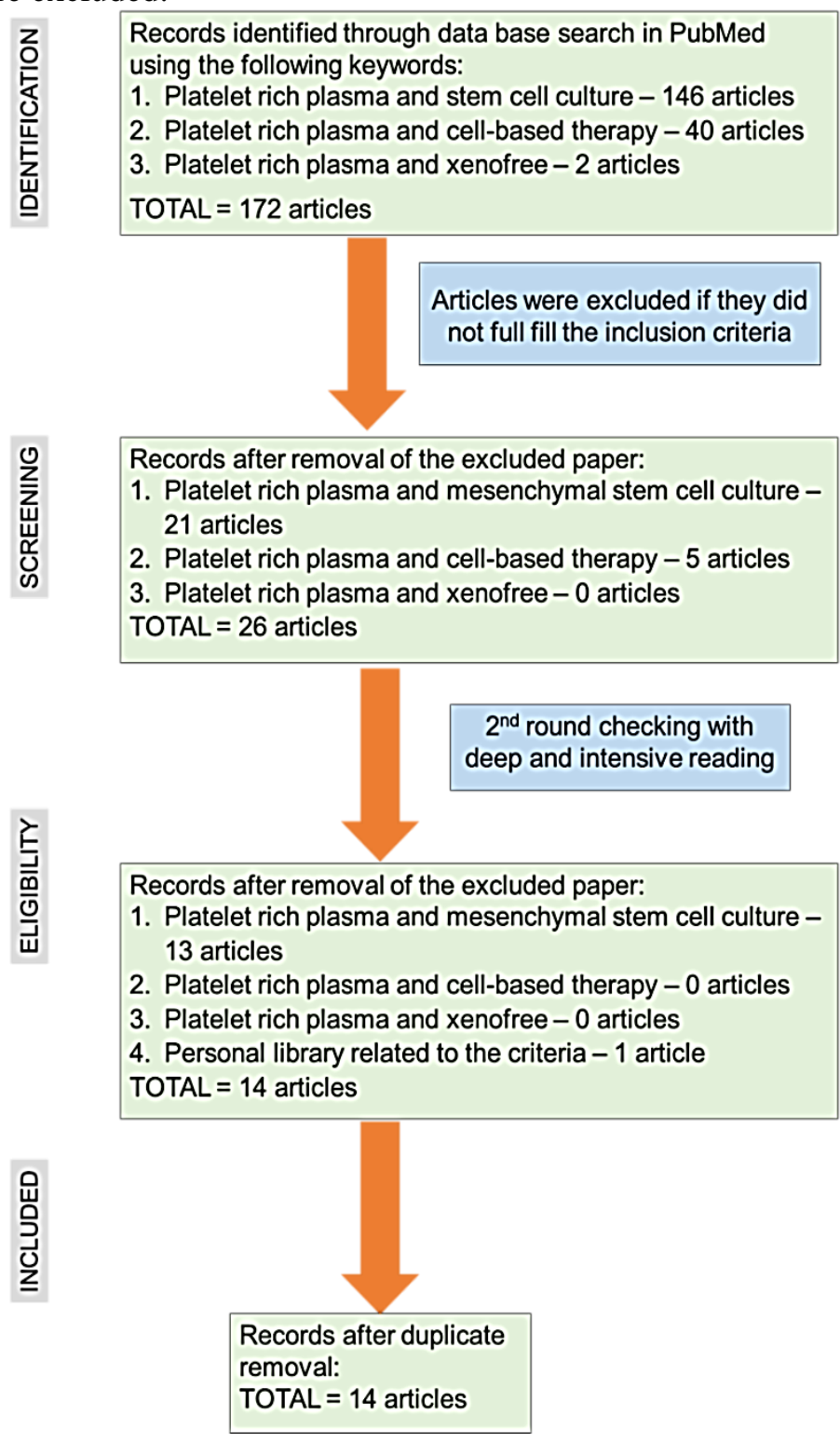

\section{Risk of bias and quality assessment}

The methodological quality of the literature search, including determining which studies to include, was independently conducted and assessed by two reviewers.

\section{RESULTS}

Based on the selection methods, 172 articles were initially found (Fig. 1). Although most of these articles reflect the use of PRP in stem cell experiments, it is evident that the use of PRP as an alternative to animal sera is still not widely implemented. The articles showed PRP application in related to MSCs in various methods; these included in vivo study designs using animals, which were used conjointly to scaffold or by directly applying (injecting) the PRP alone or with the stem cell for tissue repair or regeneration without involving prior cell culture. Only several studies have used PRP for human MSC culture, as demonstrated by 14 eligible articles that met the inclusion criteria and were then analyzed. Their characteristics are summarized in Table 1.

\section{Exclusion criteria:}

1. The cells were not human mesenchymal stem cell

2. Animal study

3. Review / systematic review article

\section{Exclusion criteria:}

1. The PRP did not use as a culture supplement (such as direct injection, mixed with scaffolds, etc)

2. The stem cells were not expanded using PRP (directly apply)

3. The form of platelet was not PRP (such as PRF)

Fig. 1: The selection process of the articles included in this study 
The mesenchymal stem cells used in these studies were derived from various tissues ranging from adipose tissue, bone marrow, umbilical cords, endometrial stroma, deciduous teeth, synovium tissue, and dental pulp. The first two were the most widely used for PRP applications. This was in accordance with other studies that have shown that adipose tissue and bone marrow are rich sources of human MSCs $(5,19,20)$.

The final result articles show that the application of PRP in human MSC culture will enhance the proliferation and differentiation capacity of the cells. Cell proliferation is a crucial component of tissue regeneration. During the healing process, cells have to enter and progress through the cell cycle, which results in an increase in cell count due to mitosis or cell dividing. These newly formed cells replace the old or damaged cells, thus regenerating the injured tissue crucial component of tissue regeneration (21).

Cell migration and differentiation are also substantial during tissue regeneration. According to the findings in the result articles, PRP application in MSC culture stimulates migration and cell differentiation. This result shows the importance of PRP in stimulating undifferentiated stem cells to migrate according to the concentration of the PRP growth factor and in triggering differentiation of these cells once they are at the site of the injured tissue. This process is essential during tissue regeneration, such as the healing process of the wound or bone tissues $(22,23)$. The concentration of PRP used in the included articles varied, ranging from $2 \%$ to $20 \%$. The studies also reported the dose-related effect of the PRP when applied to MSC culture.

These findings provide evidence that when applied to MSC culture, PRP can stimulate major cell functions such as proliferation, migration, and differentiation, which are important for tissue regeneration. This could partly explain the underlying mechanism of the regenerative capacity of PRP in the wound and musculoskeletal tissues $(24,25)$.

Table 1: Summary of the use of PRP as a biological stimulant in mesenchymal stem cell culture

\begin{tabular}{|c|c|c|c|}
\hline Type of stem cells & Characteristic findings & $\begin{array}{c}\text { Biological } \\
\text { effects }\end{array}$ & Reference \\
\hline $\begin{array}{l}\text { Human adipose-derived stem } \\
\text { cells (hADSCs) }\end{array}$ & $\begin{array}{c}\text { PRP promotes cell proliferation and chondrogenesis } \\
\text { through increases in glycosaminoglycan (GAG) and } \\
\text { TGF- } \beta 1 \text { secretion and mRNA expression of collagen } \\
\text { type- } 1\end{array}$ & $\begin{array}{l}\text { Cell } \\
\text { proliferation } \\
\quad \text { and } \\
\text { differentiation }\end{array}$ & (26) \\
\hline $\begin{array}{c}\text { Adipose-derived MSCs (h- } \\
\text { AdMSCs) }\end{array}$ & $\begin{array}{l}\text { The ratio of platelet/leukocyte during PRP preparation, } \\
\text { drove cell behavior including AdMSC proliferation } \\
\text { activity, through the balance between the } \\
\text { anabolic/catabolic. }\end{array}$ & $\begin{array}{c}\text { Cell } \\
\text { proliferation }\end{array}$ & (27) \\
\hline $\begin{array}{l}\text { - Cell of stromal fibroblasts } \\
\qquad \text { MSCs } \\
\text { - Ishikawa endometrial } \\
\text { adenocarcinoma cells (IC) }\end{array}$ & $\begin{array}{l}\text { PRP promotes endometrial regeneration through cell } \\
\text { migration, proliferation, and expression of pro- } \\
\text { inflammatory markers of cytokines, chemokines, and } \\
\text { MMPs. }\end{array}$ & $\begin{array}{l}\text { Cell } \\
\text { migration and } \\
\text { proliferation }\end{array}$ & $(28)$ \\
\hline MSCs from adipose tissue & $\begin{array}{l}\text { PRP enhances chondrogenesis through increased gene } \\
\text { expression of chondrogenic markers (Sox } 9 \text { and collagen } \\
\text { II) and also enhances chondrogenic differentiation }\end{array}$ & $\begin{array}{c}\text { Cell } \\
\text { differentiation }\end{array}$ & (9) \\
\hline $\begin{array}{l}\text { MSCs from human exfoliated } \\
\text { deciduous teeth (SHED) }\end{array}$ & $\begin{array}{c}\text { PRP showed its superiority to FBS in promoting } \\
\text { proliferation and differentiation of MSCs-SHED cells, in } \\
\text { a lower concentration. }\end{array}$ & $\begin{array}{l}\text { Cell } \\
\text { proliferation } \\
\quad \text { and } \\
\text { differentiation }\end{array}$ & (29) \\
\hline $\begin{array}{l}\text { MSCs from human exfoliated } \\
\text { deciduous teeth (SHED) }\end{array}$ & $\begin{array}{l}\text { PRP can substitute the fetal calf serum (FCS) for SHED } \\
\text { cultivation, maintaining the proliferation and } \\
\text { differentiation capacity }\end{array}$ & $\begin{array}{l}\text { Cell } \\
\text { proliferation } \\
\quad \text { and } \\
\text { differentiation }\end{array}$ & (30) \\
\hline $\begin{array}{c}\text { Human adipose-derived stem } \\
\text { cell (hADSC) }\end{array}$ & $\begin{array}{l}\text { The culture of hADSC in the presence of platelet rich } \\
\text { growth factors shows an increase in proliferation rate and } \\
\text { promotes osteogenic differentiation }\end{array}$ & $\begin{array}{l}\text { Cell } \\
\text { proliferation } \\
\text { and } \\
\text { differentiation }\end{array}$ & (31) \\
\hline $\begin{array}{c}\text { Adipose-derived MSCs (AT- } \\
\text { MSC) }\end{array}$ & $\begin{array}{l}\text { PRP in } 20 \% \text { concentration is effective in promoting } \\
\text { higher cell proliferation compared with FBS in AT-MSC, } \\
\text { without changing its differentiation capacity }\end{array}$ & $\begin{array}{c}\text { Cell } \\
\text { proliferation }\end{array}$ & (32) \\
\hline Umbilical cord-derived MSCs & $\begin{array}{l}\text { The } 10 \% \text { concentration of PRP in primary cultures } \\
\text { exhibits the highest success in promoting a faster cell } \\
\text { adherent and proliferation rate compared with FBS, while } \\
\text { maintaining their immunophenotypes, multilineage } \\
\text { differentiation potential, and does not form tumors when } \\
\text { injected at a high dose into athymic nude mice. }\end{array}$ & $\begin{array}{l}\text { Cell adherent, } \\
\text { proliferation, } \\
\quad \text { and } \\
\text { differentiation }\end{array}$ & (12) \\
\hline
\end{tabular}




\begin{tabular}{|c|c|c|c|}
\hline $\begin{array}{c}\text { Synovium-derived } \\
\text { mesenchymal stem cells }\end{array}$ & $\begin{array}{l}\text { In the presence of PRP, the cell proliferation was } \\
\text { significantly higher in the cultured cell, in all three- } \\
\text { differentiation lineages. However, PRP alone (without } \\
\text { medium differentiation), did not show the evidence to } \\
\text { promote SDSC differentiation }\end{array}$ & $\begin{array}{l}\text { Cell } \\
\text { proliferation }\end{array}$ & $(33)$ \\
\hline $\begin{array}{l}\text { Mesenchymal dental pulp stem } \\
\text { cell }\end{array}$ & $\begin{array}{l}\text { PRP in } 10 \% \text { concentration shows highly increased } \\
\text { proliferation activity by shortening the doubling time }\end{array}$ & $\begin{array}{c}\text { Cell } \\
\text { proliferation }\end{array}$ & (16) \\
\hline $\begin{array}{l}\text { Human mesenchymal stromal } \\
\text { cells from bone marrow, } \\
\text { adipose tissue, and Wharton's } \\
\text { Jelly }\end{array}$ & $\begin{array}{l}\text { 10\% PRP increases cell proliferation as compared with } \\
\text { FBS, however MSCs isolated from different tissues have } \\
\text { distinct properties regarding differentiation, angiogenic, } \\
\text { and inflammatory potential when cultured in PRP } \\
\text { supplemented media }\end{array}$ & $\begin{array}{c}\text { Cell } \\
\text { proliferation }\end{array}$ & (34) \\
\hline $\begin{array}{l}\text { Human adipose-derived stem } \\
\text { cells (hADSCs) }\end{array}$ & $\begin{array}{l}\text { PRP significantly increase cell proliferation, with less } \\
\text { osteogenic differentiation compared with FBS }\end{array}$ & $\begin{array}{c}\text { Cell } \\
\text { proliferation }\end{array}$ & $(35)$ \\
\hline Bone marrow-derived MSCs & $\begin{array}{l}\text { PRP stimulates cell proliferation in a dose-dependent } \\
\text { manner. MSC proliferation was positively correlated } \\
\text { with TGF- } \beta 1 \text { concentration, and ALP activity was } \\
\text { negatively correlated with PDGF-BB concentration in } \\
\text { PRP }\end{array}$ & $\begin{array}{c}\text { Cell } \\
\text { proliferation }\end{array}$ & $(36)$ \\
\hline
\end{tabular}

Table 2: The major growth factors in PRP

\begin{tabular}{|c|c|}
\hline Growth Factor Proteins of PRP & Major biological activities \\
\hline Platelet-derived growth factor (PDGF) & Promotes cell proliferation \\
\hline Vascular endothelial growth factor (VEGF) & Promotes neovascularization, cell survival \\
\hline TGF- $\beta$ (transforming growth factor) & Promotes cell proliferation, differentiation \\
\hline Hepatocyte growth factor (HGF) & $\begin{array}{c}\text { Stimulates mitogenesis, cell motility, and matrix } \\
\text { invasion }\end{array}$ \\
\hline Epidermal growth factor (EGF) & Stimulates cell growth/proliferation and differentiation \\
\hline Insulin-like growth factor (IGF)-1 & Stimulates cell proliferation and migration \\
\hline Fibroblast growth factor (bFGF) & Stimulates angiogenesis, cell differentiation \\
\hline
\end{tabular}

\section{DISCUSSION}

Platelets are nucleated fragments of megakaryocytes that originate from bone marrow and migrate into the bloodstream, circulating for 7-10 days. As cellular elements, platelets contain a wide protein content in the form of secretory granules (25). Platelet-rich plasma (PRP) is a human platelet concentrated in small volumes of plasma; it is known to be rich in major proteins of growth factors that are actively secreted for wound healing initiation. Moreover, PRP contains major blood proteins such as fibrin, fibronectin, and vitronectin. These proteins are essential for cell adhesion molecules and as a matrix for bone, connective tissue, and epithelial cell migration (37).

As summarized in Table 1, studies reveal that PRP application in MSC culture could promote cell proliferation, migration, and differentiation - the main physiological functions of stem cells, which are required for tissue regeneration. The effect of PRP on MSC culture in part is due to its rich content of secretory granules of various growth factors, chemokines, cytokines, and other plasma proteins (37-41). The growth factor proteins of PRP are summarized in Table 2.

Our results suggest that in the near future it would be possible to replace animal sera for MSC culture with PRP. PRP is not only suitable for maintaining MSC culture but also shows its superiority to FBS in stimulating cell proliferation, migration, and differentiation. The PRP concentration showing superior effects to FBS ranges from 10 to $20 \%$ $(12,16,32,34)$. After activated, PRP releases its secretory granules enriched with growth factors, including PDGF, VEGF, TGF- $\beta$, HGF, EGF, IGF, and FGF. These growth factors are suggested as the active biological agents that promote cell proliferation, migration, and differentiation. When PRP is used as a supplement in stem cell culture, the growth factors will interact with the cells to influence their biological activities. After being secreted, the growth factors will bind to the outer surface of the cell membrane of the affected cells, such as mesenchymal stem cells, fibroblasts, osteoblasts, endothelial cells and epidermal cells which express the receptor of

PRP-derived growth factors (37). The important message is that the active secretion of these growth factors is initiated by the clotting process of the blood, therefore the PRP should be in anti-coagulated state before use. The underlying mechanism of the mitogenic effect of PRP in MSCs proliferation is suggested through multiple signalling. A previous study using BrdU incorporation assay demonstrated that PRP induced the increase of BrdU incorporation which showed the stimulation of DNA synthesis. In addition, PRP also promotes cell cycle transition from G0/G1 to $S$ phase, therefore promoting cell to proliferate. Moreover, PRP also works through 
activating the phosphorylation of ERK1/2, Akt and JNK which is known as crucial pathway for cell proliferation (42). All of these effects indicated the potential of PRP in promoting cell proliferation and growth.

The differentiation process promoted by PRP translated the MSCs into various cell types, such as chondrogenic, osteogenic, adipogenic, and neurogenic differentiation. Research conducted by Elgamal et al. (2019) used 10\% PRP in culture medium for MSCs from adipose tissue, showing an increase in neurogenic proliferation and differentiation (43). Another study showed the effect of PRP in promoting the AD-MSCs differentiation into chondrogenesis (9). Based on our article results, most studies in MSCs differentiation using PRP supplement, showed that PRP can maintain the differentiation capacity of the MSCs, especially the multi-lineage differentiation potential into three lineages of differentiation: osteogenic, chondrogenic and adipogenic. It is suggested that the growth factors contained within PRP also contribute to cell differentiation. Studies have revealed that TGF- $\beta$ and PDGF are the potent growth factors for cell differentiation. These growth factors are suggested to work by binding to the extracellular domain of the targeted receptor which leads to the activation of the intracellular signal transduction pathway and stimulates cell differentiation $(44,45)$.

Our review showed that PRP is prominently beneficial for human MSC culture in terms of enhancing the capacity of cell proliferation, migration, and differentiation. Thus, it is possible to use PRP to replace the animal sera in human MSC culture to support a xeno-free culture system and enhance the potential use of human MSC in clinical settings.

\section{CONCLUSION}

Few studies use PRP as a growth factor supplement/ stimulant for human mesenchymal stem cell culture. This suggests that PRP is still less popular than FBS. Our results have revealed and showed the potential of human PRP as a biological supplement in human MSC culture, acting as an alternative to FBS or other animal sera. Our results indicated the potential benefit of PRP for providing a xeno-free culture method for human MSCs which supports the clinical applications of MSCs in regenerative medicine. Further studies are required to understand the detailed mechanism pathway explaining how PRP stimulates cell proliferation and differentiation.

\section{ACKNOWLEDGEMENT}

This study was supported by a research grant from the Ministry of Research and Technology / National Research and Innovation Agency (RISTEK-BRIN) of the Republic of Indonesia (Hibah PDUPT-NKB2744/UN2.RST/HKP.05.00/2020).

\section{CONFLICT OF INTEREST}

The authors have no conflicts of interest to declare.

\section{REFERENCES}

1. Srijaya, T. C., Ramasamy, T. S., Kasim, N. H. A. Advancing stem cell therapy from bench to bedside: lessons from drug therapies. J Transl Med [Internet]. 2014;12(243):1-17. Available from: http://translationalmedicine.biomedcentral.com/articles/10.1186/s12967-0140243-9

2. Dai, R., Wang, Z., Samanipour, R., Koo, K., Kim, K. Adipose-Derived Stem Cells for Tissue Engineering and Regenerative Medicine Applications. Stem Cells Int [Internet]. 2016; 1-19.

3. Brown, C., McKee, C., Bakshi, S., Walker, K., Hakman, E., Halassy, S., et al., Mesenchymal stem cells: Cell therapy and regeneration potential. J Tissue Eng Regen Med. 2019; 13(9): 1738-1755.

4. Dominici, M., Blanc, K. L., Mueller, I., Slaper-Cortenbach, I., Marini, F., Krause, D. S., et al., Minimal criteria for defining multipotent mesenchymal stromal cells. The International Society for Cellular Therapy position statement. Cytotherapy [Internet]. 2006 Jan 1 [cited 2019 Dec 2]; 8(4): 315-317.

5. da Silva, M. L., Chagastelles, P. C., Nardi, N. B. Mesenchymal stem cells reside in virtually all post-natal organs and tissues. J Cell Sci [Internet]. 2006; 119(11): 22042213.

6. Kwon, A., Kim, Y., Kim, M., Kim, J. M. J., Choi, H., Jekarl, D. W., et al.,Tissue-specific Differentiation Potency of Mesenchymal Stromal Cells from Perinatal Tissues. Sci Rep [Internet]. 2016; 6(23544): 1-11.

7. Silva, G. V., Litovsky, S., Assad, J. A. R., Sousa, A. L. S., Martin, B. J., Vela, D., et al., Mesenchymal stem cells differentiate into an endothelial phenotype, enhance vascular density, and improve heart function in a canine chronic ischemia model. Circulation. 2005; 111(2): 150-156.

8. Cho, J., D’Antuono, M., Glicksman, M., Wang, J., Jonklaas, J. A review of clinical trials: mesenchymal stem cell transplant therapy in type 1 and type 2 diabetes mellitus. Am J Stem Cells [Internet]. 2018; 7(4): 82-93.

9. Ramezanifard, R., Kabiri, M., Ahvaz, H. H. Effects of platelet rich plasma and chondrocyte co-culture on msc chondrogenesis, hypertrophy and pathological responses. J Exp Clin Sci. 2017; 16: 1031-1045.

10. Sarfraz, A., Qureshi, A. S., Fakhar-I-Adil, Usman, M. Use of autologous platelet-rich plasma versus fetal bovine serum in mesenchymal stem cells culture media. EC Vet Sci. 2019; 2: 122-128.

11. Agostini, F., Polesel, J., Battiston, M., Lombardi, E., Zanolin, S., Da Ponte, A., et al., Standardization of platelet releasate products for clinical applications in cell therapy: a mathematical approach. J Transl Med [Internet]. 2017 Dec 19 [cited 2020 Nov 25]; 15(107): 1-10.

12. Van, P. P., Vu, N. B., Pham, V. M., Truong, N. H., Pham, T. L. B., Dang, L. T. T., et al., Good manufacturing practicecompliant isolation and culture of human umbilical cord blood-derived mesenchymal stem cells. J Transl Med [Internet]. 2014; 12(56): 1-10.

13. Raeissadat, S. A., Babaee, M., Rayegani, S. M., Hashemi, Z., Hamidieh, A. A., Mojgani, P., et al., An overview of platelet products in the Iranian studies. Futur Sci OA. 2017; 3(4): 115 .

14. Kieb, M., Sander, F., Prinz, C., Adam, S., Mau-Möller, A., Bader, R., et al., Platelet-rich plasma powder: a new preparation method for the standardization of growth factor concentrations. Am J Sports Med. 2017; 45(4): 954-960.

15. Schär, M. O., Diaz-Romero, J., Kohl, S., Zumstein, M.A., Nesic, D. Platelet-rich Concentrates Differentially Release Growth Factors and Induce Cell Migration In Vitro. Clin Orthop Relat Res [Internet]. 2015 May 1 [cited 2020 Nov 26]; 
473(5): 1635-1643.

16. Kleplová, T. S., Soukup, T., Řeháček, V., Suchánek, J. Human Plasma and Human Platelet-Rich Plasma As a Substitute for Fetal Calf Serum During Long-Term Cultivation of Mesenchymal Dental Pulp Stem Cells. ACTA MEDICA (Hradec Králové) [Internet]. 2014 Jan 27 [cited 2020 Nov 25]; 57(3): 119-126.

17. Vokurka, J., Gopfert, E., Blahutkova, M., Buchalova, E., Faldyna, M. Concentrations of growth factors in platelet-rich plasma and platelet-rich fibrin in a rabbit model. Vet Med (Praha). 2016; 61(10): 567-570.

18. Lubkowska, A., Dolegowska, B., Banfi, G. Growth factor content in PRP and their applicability in medicine. J Biol Regul Homeost Agents. 2012; 26(2 Suppl): 3S-22S.

19. Shiraishi, K., Kamei, N., Takeuchi, S., Yanada, S., Mera, H., Wakitani, S., et al., Quality Evaluation of Human Bone Marrow Mesenchymal Stem Cells for Cartilage Repair. Stem Cells Int [Internet]. 2017; 2017: 1-9.

20. Lu, H., Wang, F., Mei, H., Wang, S., Cheng, L. Human adipose mesenchymal stem cells show more efficient angiogenesis promotion on endothelial colony-forming cells than umbilical cord and endometrium. Stem Cells Int [Internet]. 2018 [cited 2019 Mar 25]; 2018: 1-15.

21. Krafts, K. P. Tissue repair: The hidden drama [Internet]. Vol. 6, Organogenesis. Taylor \& Francis; 2010 [cited 2020 Oct 29]. p. 225-233.

22. King, R. S., Newmark, P. A. The cell biology of regeneration. Journal of Cell Biology. The Rockefeller University Press; 2012; 196; 553-562.

23. Kondo, T. Timing of skin wounds. Leg Med. 2007; 9(2): 109114.

24. Bretschneider, H., Quade, M., Lode, A., Gelinsky, M., Rammelt, S., Zwingenberger, S., et al., Characterization of naturally occurring bioactive factor mixtures for bone regeneration. Int J Mol Sci. 2020; 21(4): 1-15.

25. Conde-Montero, E., de la Cueva Dobao, P., González, M.J.M. Platelet-rich plasma for the treatment of chronic wounds: evidence to date. Chronic Wound Care Manag Res [Internet]. 2017; 4: 107-120.

26. Rosadi, I., Karina, K., Rosliana, I., Sobariah, S., Afini, I., Widyastuti, T., et al.,. In vitro study of cartilage tissue engineering using human adipose-derived stem cells induced by platelet-rich plasma and cultured on silk fibroin scaffold. Stem Cell Res Ther [Internet]. 2019 Dec 4 [cited 2020 Nov 26]; 10(1): 1-15.

27. de Melo, B. A. G., Luzo, Â. C. M., Lana, J. F. S. D., Santana, M. H. A. Centrifugation conditions in the L-PrP preparation affect soluble factors release and mesenchymal stem cell proliferation in fibrin nanofibers. Molecules [Internet]. 2019 [cited 2020 Nov 26]; 24(15): 1-14.

28. Aghajanova, L., Houshdaran, S., Balayan, S., Manvelyan, E., Irwin, J.C., Huddleston, H.G., et al., In vitro evidence that platelet-rich plasma stimulates cellular processes involved in endometrial regeneration. J Assist Reprod Genet [Internet]. 2018 Feb 5 [cited 2020 Nov 25]; 35(5): 757-70.

29. Wen, J., Li, H. T., Li, S. H., Li, X., Duan, J. M. Investigation of modified platelet-rich plasma (mPRP) in promoting the proliferation and differentiation of dental pulp stem cells from deciduous teeth. Brazilian J Med Biol Res [Internet]. 2016 [cited 2020 Nov 26]; 49(10): 1-8.

30. Suchánek, J., Kleplová, T.S., Řeháček, V., Browne, K.Z., Soukup, T. Proliferative capacity and phenotypical alteration of multipotent ecto-mesenchymal stem cells from human exfoliated deciduous teeth cultured in xenogeneic and allogeneic media. Folia Biol (Czech Republic). 2016; 62(1): $1-14$.

31. Ceci, C., Niada, S., Del Fabbro, M., Lolato, A., Taschieri, S., Giannasi, C., et al., Does freeze-thawing influence the effects of platelet concentrates? an in vitro study on human adiposederived stem cells. J Craniofac Surg. 2016; 27(2): 398-404.

32. Atashi, F., Jaconi, M. E. E., Pittet-Cuénod, B., Modarressi, A. Autologous platelet-rich plasma: A biological supplement to enhance adipose-derived mesenchymal stem cell expansion.
Tissue Eng - Part C Methods [Internet]. 2015 Mar 1 [cited 2020 Nov 25]; 21(3): 253-262.

33. Lee, J. K., Lee, S., Han, S. A., Seong, S. C., Lee, M. C. The effect of platelet-rich plasma on the differentiation of synovium-derived mesenchymal stem cells. J Orthop Res. 2014; 32(10): 1317-1325.

34. Amable, P. R., Teixeira, M. V. T., Carias, R. B. V., Granjeiro, J. M., Borojevic, R. Mesenchymal stromal cell proliferation, gene expression and protein production in human plateletrich plasma-supplemented media. PLoS One [Internet]. 2014 Aug 12 [cited 2020 Nov 25];9(8): 1-8.

35. Tavakolinejad, S., Khosravi, M., Mashkani, B., Bideskan, A. E., Mossavi, N. S., Parizadeh, S. M. R., et al., The effect of Human platelet-rich plasma on adipose-derived stem cell proliferation and osteogenic differentiation. Iran Biomed J [Internet]. 2014 [cited 2020 Nov 26];18(3): 150-156.

36. Cho, H. S., Song, I. H., Park, S. Y. Y., Sung, M. C., Ahn, M. W. W., Song, K. E. Individual variation in growth factor concentrations in platelet-rich plasma and its influence on human mesenchymal stem cells. Korean J Lab Med [Internet]. 2011 Jul 1 [cited 2020 Nov 25]; 31(3): 212-218.

37. Marx, R. E. Platelet-Rich Plasma: Evidence to Support Its Use. J Oral Maxillofac Surg. 2004; 62(4): 489-496.

38. Sari, P., Luviah, E., Nugraha, Y., Pawitan, A.J.L., Purwoko, R.Y. Various growth factor yields in various platelet rich plasma processing methods. Biotechnology. 2010; 9(11): 475-478.

39. Pawitan, A. J. Platelet Rich Plasma in Xeno-Free Stem Cell Culture: The Impact of Platelet Count and Processing Method. Curr Stem Cell Res Ther. 2012; 7(5): 329-335.

40. Alves, R., Grimalt, R. A Review of Platelet-Rich Plasma: History, Biology, Mechanism of Action, and Classification. Ski Appendage Disord [Internet]. 2018; 18-24.

41. Dinescu, S., Ignat, S., Simion, T.V., Selaru, A., Samoila, I., Jianu, D., et al., Multiple benefits of platelet-rich plasma for regenerative medicine therapies. Rom Biotechnol Lett. 2018; 23(5): 13933-13939.

42. Lai, F., Kakudo, N., Morimoto, N., Taketani, S., Hara, T., Ogawa, T., et al., Platelet-rich plasma enhances the proliferation of human adipose stem cells through multiple signaling pathways. Stem Cell Res Ther [Internet]. 2018 Apr 16 [cited 2020 Dec 8]; 9(107): 1-10.

43. Elgamal, A., Asmaa, A. A., Abd-Elmaksoud, A., Kassab, M., Farag, A., Lashen, S., et al., Xeno-free trans-differentiation of adipose tissue-derived mesenchymal stem cells into glial and neuronal cells. Am J Stem Cells [Internet]. 2019; 8(2): 38-51.

44. Ng, F., Boucher, S., Koh, S., Sastry, K. S. R., Chase, L., Lakshmipathy, U., et al., PDGF, TGF- $\square$ And FGF signaling is important for differentiation and growth of mesenchymal stem cells (mscs): Transcriptional profiling can identify markers and signalig pathways important in differentiation of MSCs into adipogenic, chondrogenic, and osteo. Blood. 2008; 112(2): 295-307.

45. Van der Kraan, P. M., Blaney Davidson, E. N., Blom, A., van den Berg, W. B. TGF-beta signaling in chondrocyte terminal differentiation and osteoarthritis. Modulation and integration of signaling pathways through receptor-Smads. Osteoarthr Cartil. 2009 Dec 1; 17(12): 1539-1545. 